\title{
Three-way interactions between crop plants, phytopathogenic fungi, and mirid bugs. A review
}

\author{
Alain Ratnadass ${ }^{1,2}$ (D) Jean-Philippe Deguine ${ }^{3}$ \\ Accepted: 31 October 2020 / Published online: 18 November 2020 \\ (C) INRAE and Springer-Verlag France SAS, part of Springer Nature 2020
}

\begin{abstract}
Miridae is the largest Heteroptera family, with a tremendous worldwide economic impact, both as pests and natural enemies. Unlike most Hemiptera, herbivorous and omnivorous mirid bugs are lacerate/macerate and flush feeders, not phloem feeders. Plant responses to damage by arthropods of this feeding guild therefore occur via jasmonic acid or ethylene signaling pathways rather than the salicylic acid pathway. Moreover, unlike most other Heteroptera that lay eggs on the plant surface, mirids insert their eggs in plant tissues, resulting in oviposition injury. Similarly, regarding phytopathogenic fungi and oomycetes, a distinction should be made between biotrophic fungi (triggering the salicylic acid pathway plant response), and necrotrophic and/or hemibiotrophic fungi or oomycetes (triggering jasmonic acid or ethylene pathway plant responses). In that respect, phytopathogenic fungi or oomycetes (PFO) differ from phytopathogenic viruses and bacteria, the former being all biotrophic while the latter are theoretically hemibiotrophic. Here, for the first time, we review tripartite interactions between mirids, PFO, and crop plants. The major deliverables are as follows: Five major interaction frameworks are identified: (i) crop plant infection by PFO mechanically facilitated by prior mirid infestation; (ii) crop plant infection by PFO hampered by prior mirid infestation via crop plant signaling; (iii) crop plant infestation by mirids facilitated by prior PFO infection via crop plant signaling; (iv) crop plant infestation by mirids hampered by prior PFO infection via crop plant signaling; (v) crop plant infestation by mirids and/or infection by PFO hampered by prior mirid infestation and/or PFO infection via crop plant resource quality alteration. PFO and mirids may also occur concomitantly, favored by the same conditions, i.e., climatic or linked to endogeneous factors (e.g., redox status) in crop plant. Instances from each framework are described, and highlighted interactions are examined in view of managing mirid-PFO complexes on crop plants.
\end{abstract}

Keywords Biotrophic $\cdot$ Grain mold $\cdot$ Herbivorous $\cdot$ Heteroptera $\cdot$ Mango $\cdot$ Miridae $\cdot$ Necrotrophic $\cdot$ Omnivorous $\cdot$ Powdery mildew · Sorghum

\section{Contents}

1 Introduction

2. Crop plant infection by phytopathogenic fungi is facilitated by prior mirid bug infestation

3. Crop plant infection by phytopathogenic fungi is hampered by prior mirid bug infestation

4. Crop plant infestation by mirid bugs is facilitated by prior phytopathogenic fungus infection

Alain Ratnadass

alain.ratnadass@cirad.fr

CIRAD, UPR HortSys, Réunion, F-97455 Saint-Pierre, France

HortSys, Univ Montpellier, CIRAD, Montpellier, France

3 CIRAD, UMR PVBMT, Réunion, F-97410 Saint-Pierre, France
5. Crop plant infestation by mirid bugs is hampered by prior phytopathogenic fungus infection

6. Other potential pathways

7. Implications in terms of management measures

7.1. Chemical and mineral control

7.2. Physical methods

7.3. Host plant resistance

7.4. Biological control

7.5. Plant species diversity deployment

7.6. Agroecological crop protection

8. Conclusion

Acknowledgements

References 


\section{Introduction}

Plant pathogens and arthropod pests individually or cumulatively have an adverse impact on crop plant health, generally leading to crop damage and loss, and sometimes plant mortality (Oerke 2006). Plant pathogens (Savary et al. 2012), particularly phytopathogenic fungi and oomycetes (Meng et al. 2009), cause many highly destructive plant diseases, often with severe economic consequences for farmers.

For instance, in the European Union alone, late blight caused by the oomycete Phytophthora infestans (responsible for the disastrous Irish famine in the mid-nineteenth century; Wheeler Jr 1981) still causes annual losses (control and damage costs) estimated at more than $€ 1.0$ billion (Haverkort et al. 2008). Otherwise, insect pests were estimated to cause an average annual loss of $7.7 \%$ in crop production in Brazil alone, corresponding to a total annual economic loss of approximately US $\$ 17.7$ billion (Oliveira et al. 2014). In China, the plant bug Apolygus lucorum alone is held responsible for cotton yield losses of up to 20-30\% every year (Zhang et al. 2017).

Stout et al. (2006) assessed plant-mediated interactions between pathogenic microorganisms and herbivorous arthropods. Hatcher (1995) and Rostas et al. (2003) reviewed three-way interactions between plant pathogenic (or phytopathogenic) fungi or oomycetes (hereafter referred to as PFO), herbivorous insects (of all types), and their host plants. In addition, Mitchell (2004) investigated the vectorial status of Heteroptera regarding plant pathogens of all types, and Hauser et al. (2013) conducted a meta-analysis on the combined (synergistic or antagonistic) effects of herbivorous arthropods and phytopathogens on plant performance.

However, specific three-way (or tripartite) interactions between PFO and plant bugs belonging to the Miridae family (the largest family in the Heteroptera sub-order), hereafter referred to as mirid bugs (MB), have to our knowledge never been reviewed. Here, we specifically review such interactions for this Heteroptera group, which is relevant for two major reasons.

Firstly, the Miridae family is of tremendous economic importance since it encompasses both major crop pests (the incidence of some increasing as emerging pests on crops genetically modified with Bacillus thuringiensis (Bt) genes; e.g., Lu et al. 2010; Sequeira 2019) and major natural enemies of pests (e.g., PérezHedo and Urbaneja 2015), and to a lesser extent of weeds/invasive plants (e.g., Ray and Hill 2016). Regarding the former (MB as crop pests), all possible ways to manage them without synthetic pesticides (due to their adverse environmental and sanitary impacts) have to be sought, particularly by taking advantage of biological interactions within agroecosystems. Similarly, regarding the latter two (MB as natural enemies), all possible ways to increase their efficiency should be investigated (including reduction/suppression of synthetic pesticide use).

Secondly, although true bugs, particularly MB, are generally perceived as ineffective in disseminating plant pathogens, particularly PFO (Wheeler Jr 2001), their interactions with the latter deserves further attention and investigation because MB differ from other insect groups in their relation to plant pathogens, particularly due to:

- the feeding styles of herbivorous and omnivorous MB (Fig. 1a);

- the extent of omnivory (zoophytophagy) in this group;

- their oviposition behavior, with egg insertion in plant tissues (Fig. 1b).

Indeed, among Heteroptera, there is a clearcut difference in feeding styles between herbivorous/omnivorous Cimicomorpha (Miridae, Tingidae, and Anthocoridae) on the one hand, and Pentatomorpha (e.g., Coreidae, Geocoridae, Lygaeidae, Pentatomidae, and Pyrrhocoridae) on the other (Gopalan and Subramaniam 1978; Hori 1974; Miles 1978; Wheeler Jr 2001). Contrary to the generally accepted view, herbivorous and omnivorous mirid bugs are not phloem
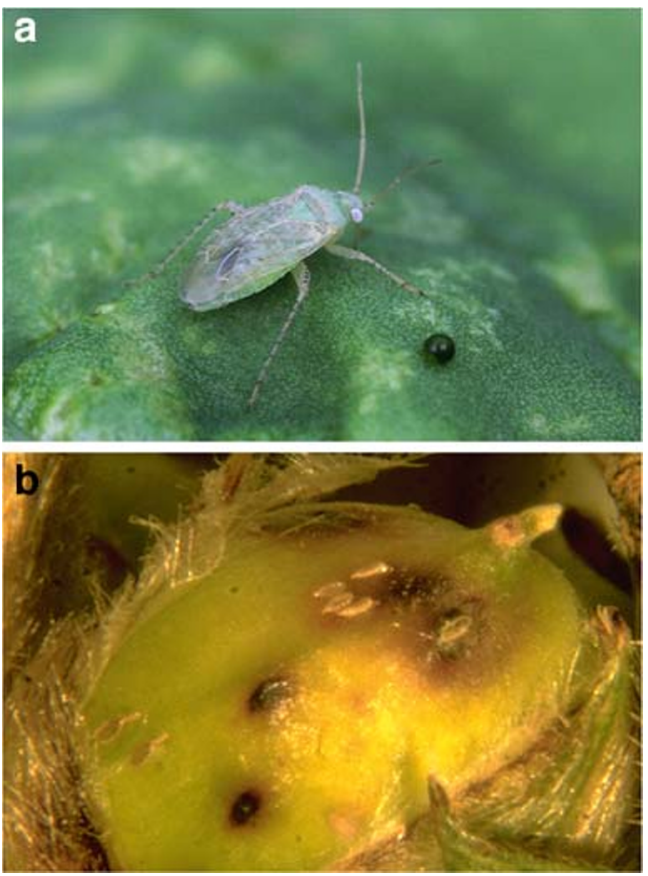

Fig. 1 a Adult Moissonia importunitas mirid bug on a rattlebox (Crotalaria spectabilis) leaf in Réunion. Yellow/light green stains are symptoms of feeding damage. Both of these symptoms and black feces are evidence of "lacerate/macerate and flush" mesophyll feeding (@ F. Le Bellec - CIRAD). b Egg-laying punctures of Eurystylus oldi and Creontiades pallidus mirid bugs on a developing sorghum kernel. Egg tips (opercula) protrude from the kernel surface. These punctures may serve as entry points for grain mold phytopathogenic fungi (ㄷ A. Ratnadass - CIRAD) 
feeders, unlike most phytophagous Heteroptera, and more generally Hemiptera, but rather either lacerate and flush (L\&F) or macerate and flush (M\&F) feeders (Cobben 1978; Hori 2000; Sharma et al. 2014; Wheeler Jr 2001). Plant responses to their damage are therefore generally via jasmonic acid (JA) or ethylene (ET) signaling pathways rather than via the salicylic acid (SA) pathway (Al-Naemi and Hatcher 2013; Karban and Chen 2007; Koornneef and Pieterse 2008; Pappas et al. 2015; Pappas et al. 2016; Wielgoss et al. 2012). However, in their review of the effects of plant fungal infection on herbivorous insects, according to both insect and pathogen lifestyles, FernandezConradi et al. (2018) overlooked the difference between phloem feeders and L\&F and M\&F feeders.

Similarly, regarding PFO, a distinction should be made between biotrophic fungi (which trigger the SA pathway plant response) and necrotrophic and/or hemibiotrophic fungi/ oomycetes (which trigger JA/ET pathway plant responses) (De Vos et al. 2005; Heidel and Baldwin 2004; Ponzio et al. 2013; Thaler et al. 2012; Walling 2000). In that respect, PFO differ from phytopathogenic viruses and bacteria, the former being all biotrophic since they need living tissue for their multiplication (Pallas and Garcia 2011), while the latter should all be considered as hemibiotrophic (Kraepiel and Barny 2016).

One typical tripartite association that is never found with $\mathrm{MB}$ is the development of sooty mold, a fungus-pest association/interaction common in other Hemiptera groups since L\&F/M\&F feeders do not exploit phloem sap, resulting in the absence of honeydew production.

Otherwise, $\mathrm{MB}$, along with most other Cimicomorpha and unlike other Heteroptera, cause oviposition injury resulting from egg insertion, because the females have a robust ovipositor which they use to drill into the host plant in order to release the egg inside the vegetative tissues (Romani et al. 2005), while Pentatomorpha lay eggs on the plant surface (Wheeler Jr 2001). Furthermore, oviposition is preceded by rostrum probing of the substrate, a process during which plant bug stylets are inserted in plant tissues (Constant et al. 1996; Ferran et al. 1996; Gopalan and Basheer 1966; Wheeler Jr 2001).

Our review does not encompass entomopathogenic fungi, non-pathogenic endophytic fungi, mycorrhizae, nor specifically mycetophagous $\mathrm{MB}$ (for these aspects, refer to Vega and Blackwell (2005)). Note however that L\&F/M\&F feeders are more likely, just like chewing herbivorous arthropods, to indiscriminately consume plant and fungus tissue, unlike sap feeders (Fernandez-Conradi et al. 2018; Mondy and CorioCostet 2004; Moran 1998; Rostas et al. 2003).

Moreover, although we focused on crop plants, when evidence from such plants was lacking in the literature, we took examples concerning weeds or invasive plants, especially when we felt that generic lessons could be drawn and applicable to crop plants. Similarly, some examples were taken from other herbivorous or omnivorous Cimicomorpha (viz. lacebugs (Tingidae) and pirate bugs (Anthocoridae)), and even other arthropod groups (viz. some herbivorous thrips (Thysanoptera) and mites (Acari)) with the same life/feeding style as herbivorous MB.

Direct and indirect interactions were defined by Willsey et al. (2017). The potential mechanisms through which crop plants, PFO, and MB interact fall within five major frameworks (Fig. 2), namely (i) CP infection by PFO mechanically facilitated by prior MB infestation; (ii) $\mathrm{CP}$ infection by $\mathrm{PFO}$ hampered by prior $\mathrm{MB}$ infestation via $\mathrm{CP}$ signaling; (iii) $\mathrm{CP}$ infestation by $\mathrm{MB}$ facilitated by prior $\mathrm{PFO}$ infection via $\mathrm{CP}$ signaling; (iv) $\mathrm{CP}$ infestation by $\mathrm{MB}$ hampered by prior $\mathrm{PFO}$ infection via CP signaling; and (v) CP infestation by $\mathrm{MB}$ and/ or infection by $\mathrm{PFO}$ hampered by prior MB infestation and/or $\mathrm{PFO}$ infection via $\mathrm{CP}$ resource quality alteration.

Otherwise, PFO and MB may also merely occur concomitantly, namely favored by the same conditions, i.e., climatic or linked to endogeneous crop plant factors (e.g., redox status; Husson 2013), triggered or not by abiotic factors. Our review focuses on the first four interaction frameworks, since the fifth one (dealing with resource quality alteration) is quite trivial and has been well described elsewhere (e.g., FernandezConradi et al. 2018). Our review does not encompass either phytotoxaemia, i.e., the case when MB feeding symptoms can be confused with those caused by chewing insects, drought, hail, high temperatures, insufficient pollination, mechanical injury, nutrient deficiency or toxicity, and pollution, but especially with plant disease symptoms (Wheeler Jr 2001), including those resulting from infection by PFO (Hori 2000; Gopalan and Subramaniam 1978). Interestingly, even the potato late blight disease was mistakenly proposed to be caused by the plant bug Lygus lineolaris (Wheeler Jr 1981).

\section{Crop plant infection by phytopathogenic fungi is facilitated by prior mirid bug infestation}

This specific aspect (dissemination of fungal pathogens) was partially reviewed by Wheeler Jr (2001). There are several examples whereby MB infestation facilitates mechanical transmission of PFO to crop plants (annual or perennial). For instance, Calonectria rigidiscula, which causes cocoa dieback, infects trees through MB (Sahlbergella singularis (Fig. 3) and Distantiella theobroma) lesions on stems (Crowdy 1947). Actually, it was reported that neither the insects nor the fungus alone normally causes serious damage to the tree, but their combined damage has a major impact on the cocoa industry in West Africa (Crowdy 1947). On cashew trees in India, the MB Helopeltis antonii was reported to be the primary causal agent of inflorescence blight, with Gloesporum mangifera, Phomopsis anacardiae, Pestaliopsis spp., and Botrydiplodia spp. associated with it as secondary saprophytic 
Fig. 2 a Main 3-way interactions between herbivorous mirid bugs (MB), phytopathogenic fungi/ oomycetes (PFO), and crop plants (CP). Solid green arrows, positive (on target organism) direct effects; solid red arrows, negative (on target organism) direct effects; dotted purple arrows, indirect effects (either positive or negative). b CP infection by $\mathrm{PFO}$ mechanically facilitated by prior $\mathrm{MB}$ infestation. $\mathrm{c} C \mathrm{P}$ infection by $\mathrm{PFO}$ hampered by prior MB infestation via $\mathrm{CP}$ signaling. $\mathbf{d} \mathrm{CP}$ infestation by $\mathrm{MB}$ facilitated by prior $\mathrm{PFO}$ infection via $\mathrm{CP}$ signaling. e $\mathrm{CP}$ infestation by $\mathrm{MB}$ hampered by prior $\mathrm{PFO}$ infection via $\mathrm{CP}$ signaling. $\mathbf{f} \mathrm{CP}$ infestation by $\mathrm{MB}$ and/or infection by PFO hampered by prior $\mathrm{MB}$ infestation and/or PFO infection via $\mathrm{CP}$ resource quality alteration. Illustrations by Simon Ratnadass
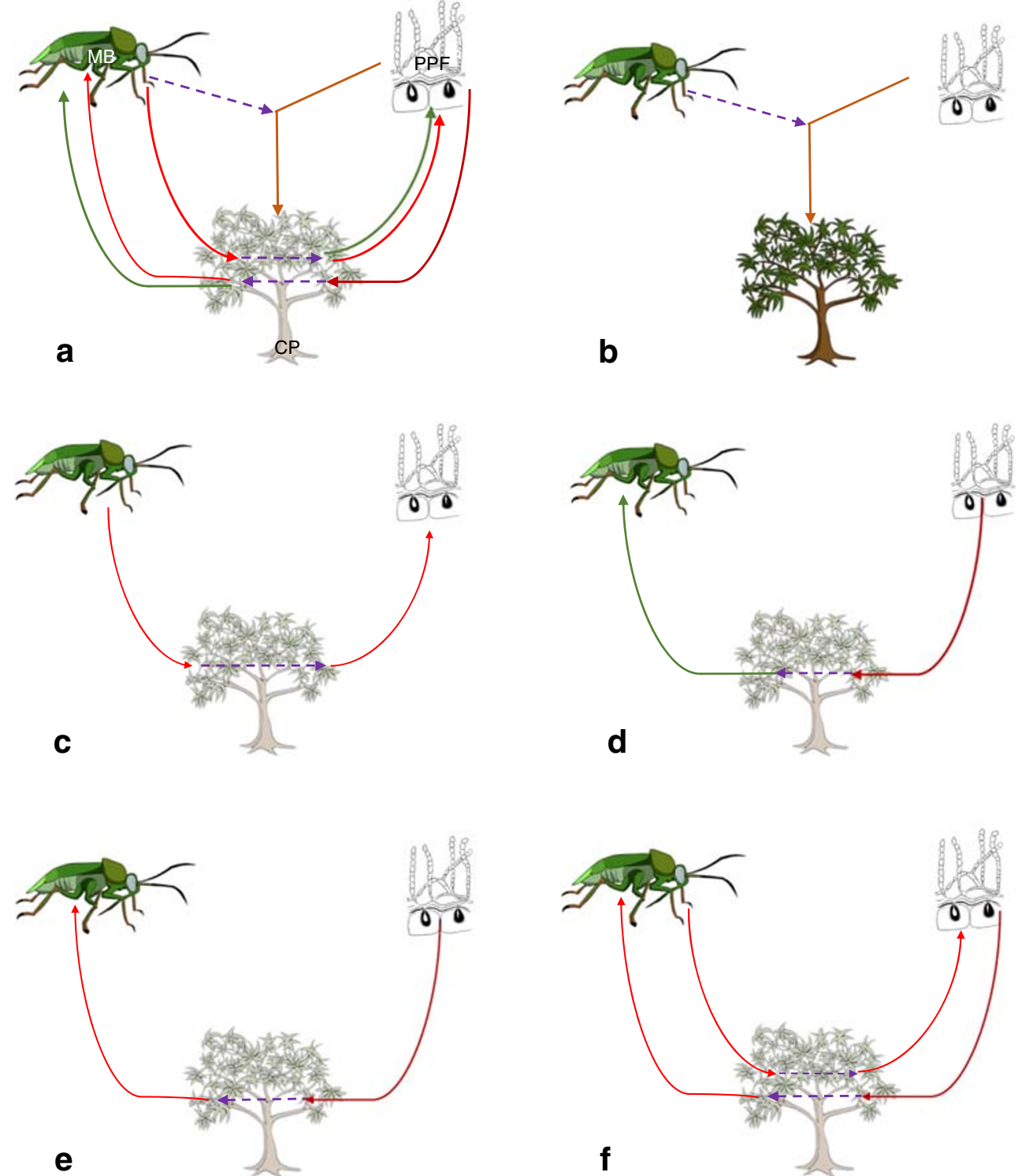

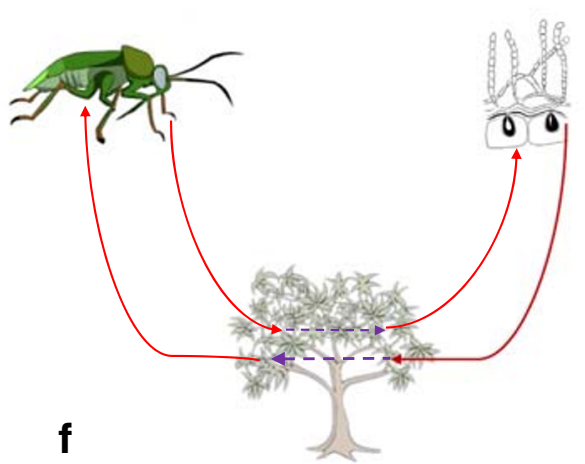

colonizers (Wijetunge et al. 2003). In addition to these quite well-documented cases, Cech (1989) suspected that MB egglaying injuries facilitate the entry of fungal pathogens of oak. In Dominica, Whitwell (1993) reported evidence of egglaying scars by MB Dagbertus sp. and Rhinacloa antennalis as sites of pathogen entry and subsequent infection in mango. This was also reported for the same MB species in avocado (Peña et al. 2003).

Besides perennial plants, several cases have been reported in annual crops, e.g., Orthops campestris as vector of the carrot phytopathogenic fungus Stemphylium radicinum (Bech 1967). In the USA, the cotton fleahopper Pseudatomoscelis serratus was suspected to contaminate cotton flower buds with various micro-organisms, particularly fungi of the genera Penicillium, Fusarium, and Alternaria (Cadou 1994; Martin Jr et al. 1987). This was also observed in the Congo with Helopeltis spp. and Colletotrichum gossypii causing cotton anthracnose (Cadou 1994; Steyaert and Vrydagh 1933; Vrydagh 1936). Lygus hesperus was also reported to be a vector of Aspergillus flavus in cotton (Stephenson and Russell 1974). However, the best documented example concerns sorghum panicle-feeding MB (mainly Eurystylus oldi)/ grain mold (Figs. $1 \mathrm{~b}$ and $4 \mathrm{a}$ and b) in West and Central Africa (Aheto et al. 2017; Marley and Malgwi 1999; Ratnadass et al. 1995; Ratnadass et al. 2003a).

Feeding/egg-laying puncture symptoms induced by panicle-feeding MB (also referred to as "head bugs") may be confused with those of grain mold infection due to phytotoxaemia (Fig. 4a and b). While grain mold fungi may penetrate sorghum grains directly under high humidity conditions, infection by these fungi can also be facilitated by biotic 


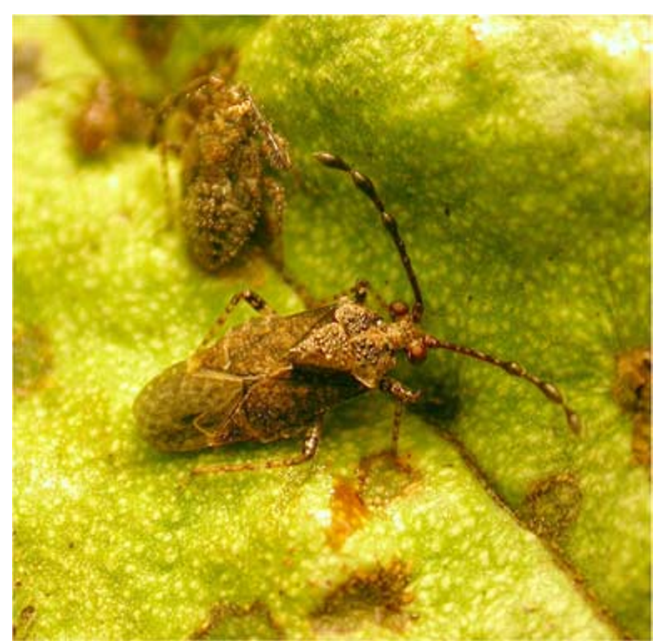

Fig. 3 Cocoa mirid bugs (Sahlbergella singularis) in Cameroon. An adult in the foreground and nymphs in the background. Brown stains are symptoms of leaf feeding damage (@ R. Babin-CIRAD)

factors, especially insects (Bandyopadhyay et al. 2000). As reviewed by Marley and Ajayi (1999), the first clear evidence of this relationship in the West and Central Africa sub-region was obtained in experiments carried out by the Institut d'économie rurale (IER) at Sotuba (Mali) in 1990 and 1991, which demonstrated a close relationship between paniclefeeding MB and grain mold (Ratnadass et al. 1995). Fungicide application only slightly affected MB damage, but grain mold damage was greater on unprotected than on fungicide-protected panicles. Yet, panicles protected from MB only with plastic bags had no more mold severity than those protected by fungicide treatment alone, or jointly by fungicide treatment and plastic bags (Ratnadass et al. 1995). This was confirmed in experiments conducted by the Institute for Agricultural Research (IAR) at Samaru (Nigeria) in 1995 and 1996 (Marley and Malgwi 1999).

The relationship between panicle-feeding MB infestation and mold infection was confirmed in the Regional Sorghum Head Bug and Grain Mold Trial conducted in 1996 and 1997 under the West and Central African Sorghum Research Network (WCASRN) in 15 research stations across 10 countries participating in the network. Insecticidal treatment had a significant impact on the grain mold incidence respectively in five and four out of 11 localities where this parameter was measured in 1996 and 1997, thus partially confirming the critical role played by panicle-feeding MB as factors aggravating mold infection (Ratnadass et al. 2003a). PFO involved in all of these cases were necrotrophic or hemibiotrophic.

\section{Crop plant infection by phytopathogenic fungi is hampered by prior mirid bug infestation}

Herbivorous or omnivorous MB may induce plant resistance to other more damaging L\&F arthropod pests, e.g.:

- Macrolophus pygmaeus vs spider mites (Pappas et al. 2015; Zhang et al. 2018) and thrips (Zhang et al. 2018) on cultivated Solanaceae;

- Tupiocoris notatus vs chewing caterpillars (Manduca sexta) on wild tobacco (Nicotiana atenuata) (Halitschke et al. 2011; Kessler and Baldwin 2004; Voelckel and Baldwin 2004);

- Helopeltis sulawesi vs the major pest/pod-boring moth Conopomorpha cramerella on cocoa in Southeast Asia (Wielgoss et al. 2012).
Fig. 4 a Eurystylus oldi induced damage on a sorghum panicle in Mali. This is a case of mere phytotoxaemia due to extensive adult feeding at the milk stage. Mirid bug punctures at a later stage may facilitate grain mold infection (C) A. Ratnadass CIRAD). b Grain mold damage on a sorghum panicle in Mali. This may or not have been facilitated by prior mirid bug punctures. Molded grains may be pink, white, or black (depending on the pathogen) (@ K. Vom Brocke - CIRAD)
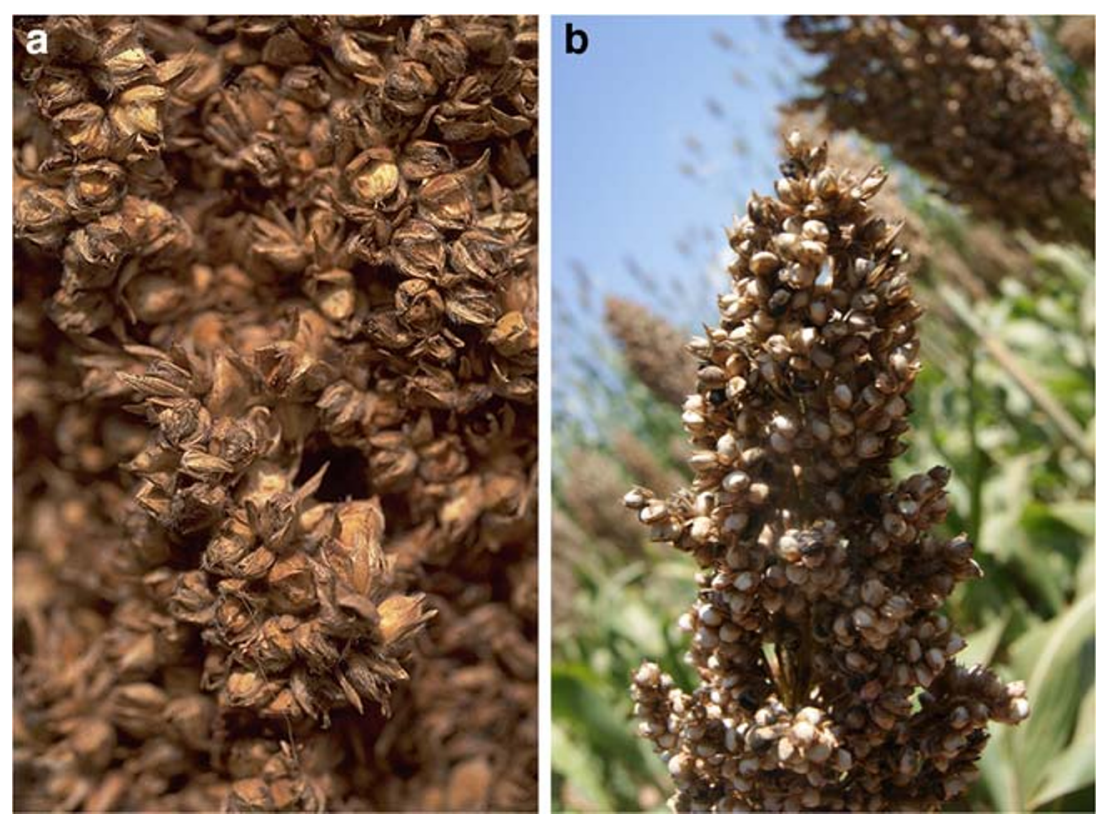
Prior infestation by some MB may also induce systemic resistance in plants against subsequent PFO infection (Karban and Chen 2007). For instance, studies on interactions between the MB Eccritotarsus catarinensis and the necrotrophic PFO Acremonium zonatum, a biocontrol agent of water hyacinth, Eichhornia crassipes, suggested an initial development of a plant defense response to MB feeding, thus delaying infection by PFO (Ray and Hill 2016).

Studies by Frati et al. (2006) showed that MB produced endo-polygalacturonase (PGs) hydrolytic enzymes that are involved in the degradation of pectin, a major plant cell wall component. Several plants are known to produce extracellular plant proteins like polygalacturonase-inhibiting proteins (PGIPs), which are known for their ability to inhibit fungal PGs and restrict fungal colonization (Frati et al. 2006). PGIPs of bean (Phaseolus vulgaris) also inhibited PGs of two MB species (Lygus rugulipennis and Adelphocoris lineolatus) and two necrotrophic PFO, i.e., Colletotrichum acutatum and Botrytis cinerea (d'Ovidio et al. 2004). PGs are also produced by A. lucorum (Zhang et al. 2015), yet prior infestation of garden balsam (Impatiens balsima) by this MB did not have any effect on powdery mildew infection (Pan et al. 2013). This absence of effect was also observed with Helopeltis spp. infestation in cashew, and Oidium anacardii infection (Agboton et al. 2013). Both of these cases involved biotrophic fungi.

Lastly, MB could potentially adversely affect fungal growth via the antifungal function of scent gland secretions. For instance, trans-2-hexenal, a volatile aldehyde which is a major compound secreted by rice stink bugs (Blum et al. 1960), was found to inhibit Aspergillus flavus growth and aflatoxin production in corn (De Lucca et al. 2011). However, this was not confirmed with regard to $\mathrm{MB}$ Adelphocoris suturalis (Zhang et al. 2014).

\section{Crop plant infestation by mirid bugs is facilitated by prior phytopathogenic fungus infection}

There are no documented examples of MB infestation of crop plants being facilitated by PFO infection, while there are many documented examples of L\&F/M\&F feeding arthropod (other than MB) infestation of CP facilitated by PFO infection (Table 1). In those cases, three fungi out of four are biotrophic (which is consistent with the CP signaling assumption), while in the case of cotton lint rot, the use of the fungus for food by the mite seems to overcome this signaling.

In the case of Orthops palus and the powdery mildew Pseudoidium anacardii (formerly Oidium mangiferae) fungus in mango, such facilitation is highly suspected in Réunion, although its pathway remains unknown (Atiama 2016; Deguine et al. 2018). O. palus and P. anacardii were found to have simultaneously caused damage. O. palus was also absent in $80 \%$ of cases when powdery mildew was absent (2387 observations over 3 years; Deguine et al. 2018). In addition, a preliminary experiment conducted in a mango orchard showed that sulfur application against powdery mildew slightly adversely affected $O$. palus, whereas powdery mildew infection was not at all affected by insecticide (Lambdacyhalothrin) treatment (Ratnadass, unpublished).

Turner et al. (2018) also reported the co-occurrence of a biotrophic PFO and a MB, i.e., Puccinia silphii and Lygus lineoralis, respectively, on the perennial oilseed crop Silphium integrifolium, although these authors did not highlight a facilitation phenomenon in that case.

\section{Crop plant infestation by mirid bugs is hampered by prior phytopathogenic fungus infection}

Some PFO, particularly Fusarium spp., produce beauvericin (Logrieco et al. 2002), which has insecticidal activity. Although this may mainly be harmful to chewing herbivores that indiscriminately consume plant and fungus tissues, and less so to piercing-sucking herbivores that only consume sap (Fernandez-Conradi et al. 2018), beauvericin may also affect L\&F/M\&F feeders, including MB, e.g., Lygus spp. (Leland et al. 2005).

A particular case concerns the natural enemy Nesidiocoris volucer on tobacco plants infested with tobacco powdery mildew caused by Golovinomyces cichoracearum in Réunion (Fontaine and Atiama, La Coccinelle ${ }^{\circledR}$, pers. com., 2019). It was assumed that mycelium hampered egg-laying, hatching, and movement of MB nymphs (Fig. 5).

\section{Other potential pathways}

The co-occurrence of MB and PFO may be due to microclimatic conditions that favor both attackers, which is (along with facilitation) a partial explanation in the case of sorghum panicle-feeding MB and grain mold (Ratnadass et al. 2003b). This hypothesis should be tested and possibly ruled out in the case of mango MB/powdery mildew (Atiama 2016; Deguine et al. 2018; Ratnadass et al. 2019). No general rule can be put forward in this respect since the relationship depends on the MB species (e.g., Ratnadass and Butler 2003), and PFO species (e.g., powdery mildew pathogens being favored by cooler and dryer conditions than those conducive to the development of pathogens responsible for grain mold; Nasir et al. 2014; Tonapi et al. 2007).

Another case of co-occurrence of MB and PFO concerns the cultivation of transgenic insect-resistant $(B t)$ cotton lines, which significantly reduced insecticide usage against Lepidopteron pests, resulting in an outbreak of pests that were 
Table 1 Documented examples of arthropod infestation of crop plants facilitated by phytopathogenic fungus infection

\begin{tabular}{|c|c|c|c|c|c|}
\hline Arthropod & Fungus/disease & $\begin{array}{l}\text { Fungus } \\
\text { trophic } \\
\text { strategy }\end{array}$ & Plant & Process & References \\
\hline Thrips tabaci & $\begin{array}{l}\text { Sphaerotheca pannosa/powdery } \\
\text { mildew }\end{array}$ & Biotroph & $\begin{array}{l}\text { Vine, rose, strawberry, } \\
\text { cantaloupe, clove }\end{array}$ & $\begin{array}{l}\text { Fungus required as } \\
\text { food for thrips }\end{array}$ & Yarwood (1943); Coyier (1983) \\
\hline Tetranychus urticae & $\begin{array}{l}\text { Sphaerotheca pannosa/powdery } \\
\text { mildew }\end{array}$ & Biotroph & Rose & $\begin{array}{l}\text { Fungus required as } \\
\text { food for mites }\end{array}$ & $\begin{array}{r}\text { Poncet et al. (2008); } \\
\text { Bout et al. (2011) }\end{array}$ \\
\hline Tetranychus spp. & $\begin{array}{l}\text { Podosphaera spp./powdery } \\
\text { mildews }\end{array}$ & Biotroph & Apple \& cherry & Unknown & Reding et al. (2001) \\
\hline $\begin{array}{l}\text { Siteroptes } \\
\quad \text { reniformis }\end{array}$ & Nigrospora oryzae/lint rot & Necrotroph & Cotton & $\begin{array}{l}\text { Fungus required as } \\
\text { food for mites }\end{array}$ & Laemmlen and Hall (1973) \\
\hline
\end{tabular}

considered secondary, particularly MB (Lu et al. 2010). On the other hand, $B t$ cotton lines also exhibited reduced disease resistance in comparison to conventional lines, especially for Fusarium wilt in China (Li et al. 2009); Bt cotton cultivation in India was also associated with an increase of damage by many PFO/diseases, e.g., R. solani and Macrophomina phaseolina root rot, Alternaria macrospora and Myrothecium leaf blight, and Ramularia areola grey mildew (Saravanan et al. 2015).

Recent research has also highlighted the role of endogenous plant factors, such as the crop plant reduction/oxidation and acidification/alkalinization (redox $/ \mathrm{pH}$ ) status in relation with soil, favoring/hampering specific types of pests/ pathogens (Bousset et al. 2019; Husson 2013), which should therefore also be considered. For instance, biotrophic fungi are associated with more alkaline media than necrotrophic fungi (e.g., those whose infection is facilitated by MB puncture). This redox/pH framework also helps explain why MB, unlike phloem-feeding Hemiptera, are poor virus and biotrophic fungi transmitters, but better at transmitting bacteria or necrotrophic fungi (Wheeler Jr 2001).

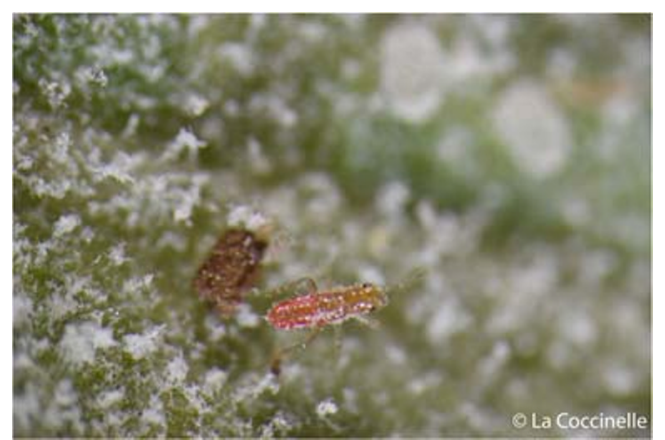

Fig. 5 Newly hatched nymph of the mirid bug Nesidiocoris volucer on a tobacco leaf in Réunion. This shows that tobacco powdery mildew mycelium hampers bug movements, while also probably deterring egglaying (@ La Coccinelle)

\section{Implications in terms of management measures}

Many action levers could eventually be mobilized based on the evidence from various crops culled in the literature, as detailed hereafter ( $\$ 7.1$ to 7.6$)$.

\subsection{Chemical and mineral control}

Synthetic insecticides (cypermethrin and deltamethrin) used in the WCASRN regional trial (Ratnadass et al. 2003a) were found to be effective against both head bugs and grain mold (although to a lesser extent for the latter). Zhang et al. (2017) reported that neonicotinoid seed treatments, particularly with nitenpyram, could provide effective protection and play an important role in the management of early season A. lucorum in Bt cotton fields in China. Moreover, seed treatments combining nitenpyram with fungicides could be a suitable choice for controlling both MB and PFO (e.g., Rhizoctonia solani and Verticillium dahliae) during the cotton seedling stage (Zhang et al. 2017).

Some mineral pesticides (like sulfur) may have a dual effect on powdery mildew and MB. This is the case in tomato regarding Oidium neolycopersici and the natural enemies Nesidiocoris tenuis and Deraeocoris brevis (potentially), which are omnivorous MB (Amarasekare and Shearer 2013; Zappalà et al. 2011). N. tenuis is presently released as natural enemy in tomato fields, yet it may turn out to be a crop pest (Arno et al. 2010). However, there are no reported instances of mainly herbivorous MB being directly controlled by powdery mildew-targeted sulfur applications. On the other hand, Fernandez et al. (2006) also found that apple fruit damage by the mullein MB Campylomma verbasci was reduced by mineral oil sprays targeting apple powdery mildew (Podosphaera leucotricha).

The use of elicitors of plant defenses, or so-called plant activators, has been proposed as an alternative approach to chemical crop protection (Bruce 2010; Sobhy et al. 2014; Thaler et al. 2001; Vallad and Goodman 2004; Worrall et al. 
2012). However, to our knowledge, no cases jointly involving $\mathrm{MB}$ and PFO have been reported.

\subsection{Physical methods}

One particular case pertains to mechanical control with a bug vac that was developed to suck $L$. hesperus MB out of strawberry fields (Dietrick 1961), but which at the same time spreads diseases like powdery mildew and gray mold (Kuepper and Thomas 2002). With such conflicting effects, tradeoffs should be sought.

On the other hand, the potential of powdery mildew inoculum removal in mango (as suggested by Misra 2001; Misra et al. 1998; Nasir et al. 2014) could be tested in Réunion, including for its effect on mango MB infestation.

\subsection{Host plant resistance}

Regarding head bugs and grain mold, sorghum varietal resistance to the former contributed to resistance to the latter, which was also the case with phenotypic plant characteristics negatively affecting both attackers in relation to microclimatic conditions (i.e., panicle laxity/openness) (Ratnadass et al. 2003a). Similarly, genetic resistance of cotton to MB pests, e.g., that due to leaf pubescence (trichome density; McLoud et al. 2015; Wood et al. 2017), is expected to reduce flower bud infection by PFO.

\subsection{Biological control}

On cotton, the fungal natural enemy Beauveria bassiana has synergistic control potential due to its dual effect on Lygus spp., as well as $R$. solani and Pythium myriotylum (Leland et al. 2005; Ownley et al. 2008). However, B. bassiana application as an augmentative biological control measure against Lygus bugs in strawberry overcomes the need for powdery mildew-specific fungicide treatments (Dara 2017).

Otherwise, regarding conservation biological control, conflicting effects were highlighted in cocoa orchards in tropical Africa. Namely, measures to encourage weaver ants (Oecophylla longinoda) and other ant species as predators of MB (Bagny-Beilhe et al. 2018) (which could reduce cocoa dieback incidence: Crowdy 1947) may result in increased incidence of black pod rot, since ants are disseminators of Phytophthora megakarya, the oomycete causative agent of the disease (Bisseleua et al. 2017).

\subsection{Plant species diversity deployment}

This refers to a set of agroecological management strategies implemented at various scales (Ratnadass et al. 2012). For instance, through the use of cover crops in conservation agriculture strategies, the redox conditions of soil and crop plants

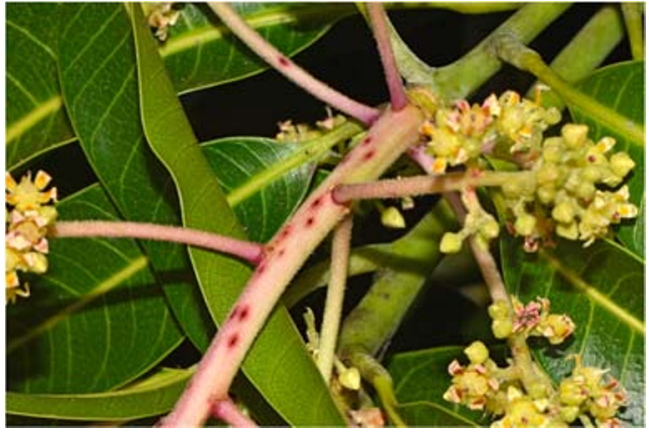

Fig. 6 Orthops palus punctures on a mango inflorescence in Réunion. Adult and nymph feeding mainly affects mature inflorescences. This results in their drying up and causes flower and young fruit drop (@) A. Franck - CIRAD)

could be altered to make them unfit for both types of attackers (Husson et al. 2016, 2018).

At the scale of the field and its margins, it was found in China that mungbean (Vigna radiatus) had considerable potential as a trap crop for A. lucorum in Bt cotton fields ( $\mathrm{Lu}$ et al. 2009). Maize (Zea mays) fields were also proposed as potential sinks for these pests (Jiao et al. 2019). In addition, buckwheat (Fagopyrum esculentum) strip crops were found to increase A. lucorum regulation in cotton by a Braconid parasitoid species (Li et al. 2019). Although no direct interactions with PFO have been highlighted for this MB species, such principles could be applied for other MB that are known for their facilitating effects for infection by $\mathrm{PFO}$, for instance, the use of sorghum as a trap crop for MB management on cotton (Ratnadass et al. 2009), or trap cropping with castor bean (Ricinus communis) to reduce sorghum infestation by Eurystylus oldi (Ratnadass et al. 2001).

Moreover, in agroforestry (AF) strategies, shade generated by $\mathrm{AF}$ trees in cocoa orchards was found to both facilitate black pod rot infection and negatively affect MB infestation (Babin et al. 2010; Gidoin et al. 2014), and hence potentially dieback incidence. With such conflicting effects, tradeoffs should be sought.

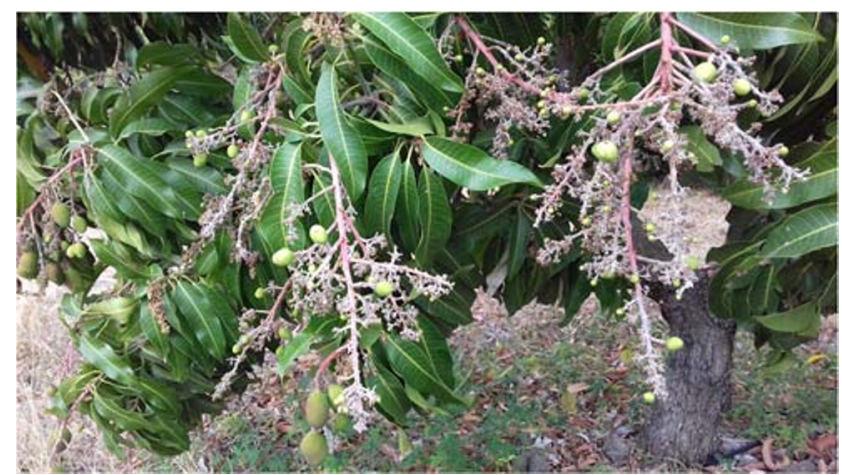

Fig. 7 Powdery mildew (Pseudoidium anacardii) on mango inflorescences in Réunion. Some inflorescences are completely covered with mycelium. This will eventually result in their browning and drying up (@ A. Ratnadass - CIRAD) 


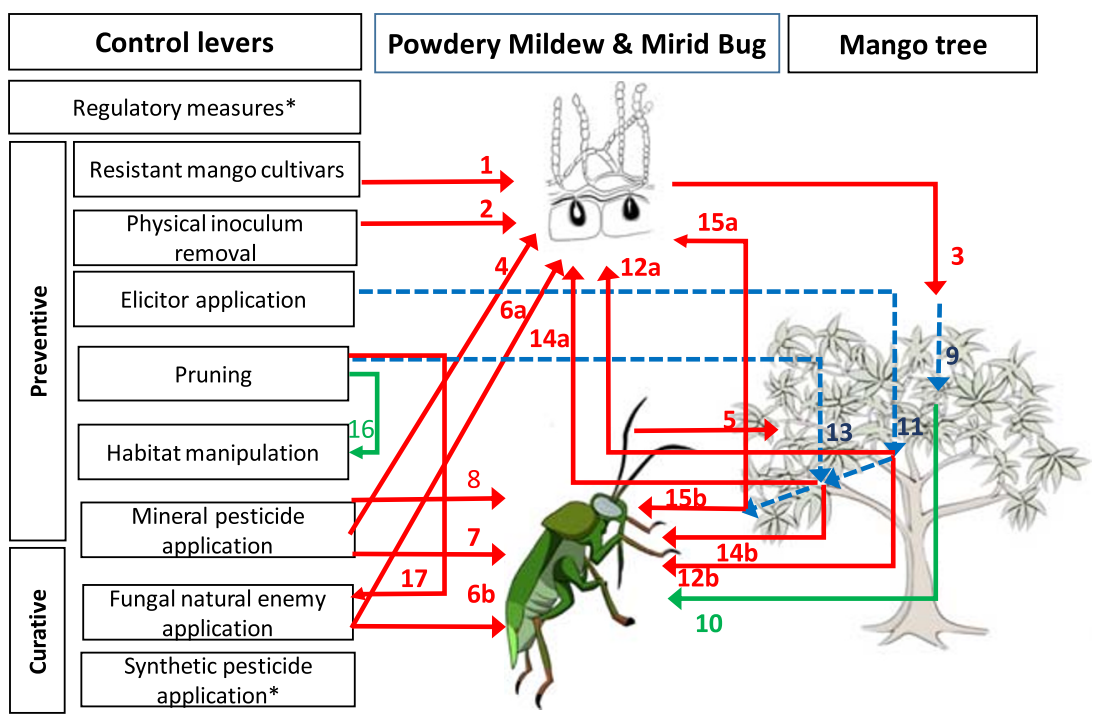

Fig. 8 Proposed strategy for agroecological protection of mango against $P$. anacardii and $O$. palus in Réunion with action levers that could be mobilized (partially adapted from Deguine et al. 2018 and Ratnadass et al. 2019). Solid green (resp. red) arrows, positive (resp. negative) direct effect on target organism or lever; dotted blue arrows, indirect effects via the crop plant. *Not applicable (no regulatory measures nor synthetic pesticide for curative control). 1. Powdery mildew-resistant mango cultivars (e.g., Joubert et al. 1993; Vincenot and Normand 2009); 2. Effectiveness of powdery mildew inoculum removal (e.g., Misra 2001; Misra et al. 1998; Nasir et al. 2014); 3. Damage caused by powdery mildew to mango inflorescences (e.g., Nasir et al. 2014); 4. Effectiveness of sulfur application against mango powdery mildew (e.g., Nasir et al. 2014); 5. Damage caused by mango MB to mango inflorescences (e.g., Atiama 2016); 6a and 6b. Potential effect of Lecanicillium lecanii as a pathogen of some powdery mildews and some MB species (e.g., Romero et al. 2003; Pasaru et al. 2014); 7. Effectiveness of sulfur application against omnivorous MB (e.g., Amarasekare and Shearer 2013; Zappalà et al. 2011); 8. Potential effect

\subsection{Agroecological crop protection}

As illustrated above, many control techniques may be used for managing MB and/or PFO, either individually or in combination, as part of IPM strategies (Barzman et al. 2015). However, those levers may also be combined within the more relevant agroecological crop protection (ACP) framework, as described by Deguine et al. (2017). Indeed, controlling crop pests and pathogens using synthetic pesticides with direct toxic activity is increasingly discouraged, while the use of more environment-friendly approaches such as ACP is essential for a more sustainable future.

While the most documented example of facilitation of fungus infection following MB infestation concerned paniclefeeding MB/grain mold in sorghum, a challenging case where the reverse was observed concerned mango $\mathrm{MB}$ and powdery mildew (Figs. 6 and 7). Although this case is still pending confirmation, it is supported by other evidence regarding herbivorous arthropods with the same feeding style as MB (see of natural enemies on $O$. palus e.g predatory Campylomma leucochila enhanced via habitat manipulation (e.g., Atiama 2016; Deguine et al. 2018; Jacquot 2016; Ratnadass et al. 2018); 9. Inhibition of JA plant response following biotrophic attack (e.g., Ponzio et al. 2013); 10. Attractiveness for $O$. palus as a necrotrophic attacker (e.g., Deguine et al. 2018); 11. Effect of elicitor application on mango flowering synchronization (e.g., Singh et al. 2001; Mohammadi et al. 2015); 12a and 12b. Potential of SA and JA plant signaling pathways against resp. $P$. anacardii and $O$. palus; 13 . Effect of pruning on mango flowering synchronization (e.g., Oosthuyse and Jacobs 1997); 14a and 14b. Potential of reduced duration of pest-susceptible stage against resp. $P$. anacardii and $O$. palus; 15 a and $15 \mathbf{b}$. Potential of microclimate alteration on suppression of resp. $P$. anacardii and $O$. palus (Ratnadass et al. 2019); 16. Potential effect of pruning on light penetration in the orchard and floor vegetation growth (including habitats for conservation biological control; e.g., Rothe et al. 2019). 17. Potential effect of pruning on fungal natural enemies via microclimate alteration (Mahot et al. 2019; Ratnadass et al. 2019). Artwork by Simon Ratnadass part 4). On this basis and that of confirmed or potential action levers, in Fig. 8, we propose a framework for management of $O$. palus and $P$. anacardii in mango orchards in Réunion according to ACP principles (including the strict order according to which these levers should be implemented).

For this mango, MB/powdery mildew case study neither the first nor the last step is applicable since, as both attackers are well established on the island, there are no regulatory measures for their control, and also synthetic pesticide treatments are likely to be banned soon for curative control.

With respect to preventive methods, there are no reports of varietal differences in resistance to MB. Regarding host plant resistance to powdery mildew among mango cultivars that have been evaluated in Réunion, Sensation was found to be less susceptible to $P$. anacardii (Joubert et al. 1993), contrary to Kent and Cogshall, both of which are highly susceptible (Vincenot and Normand 2009), with Tommy Atkins being intermediate. Regarding physical control for powdery mildew, the methods reported by Misra (2001), Misra et al. 
(1998), and Nasir et al. (2014) have not been tested in Réunion. Pruning might also have a direct effect on mango bug/powdery mildew through microclimatic effects, but also indirect effects via changes in tree phenology (particularly flowering dynamics), and effects on vegetation soil cover growth (increased available light), resulting in potential indirect effects on mango bugs through natural enemies, e.g., predatory Campylomma leucochila and potential parasitoid Leiophron sp. (Atiama 2016; Jacquot 2016; Ratnadass et al. 2018; Williams et al. 2003 ; Demirel et al. 2005). As for elicitors, a literature review suggests that JA sprays could balance endogenic SA production triggered by powdery mildew infection, without affecting flowering synchronization (Singh et al. 2001; Mohammadi et al. 2015), which is another indirect way of minimizing MB damage by reducing the duration of the susceptible stage.

With respect to curative measures, application of sulfur as a mineral fungicide could actually also be considered as preventive against $\mathrm{MB}$, since it does not seem to have a direct effect on MB. Sulfur may also have an indirect effect by hampering powdery mildew and therefore not triggering the SA pathway in host plants, resulting in non-inhibition of JA signaling, while having a negative effect on pests with necrotrophic lifestyles like MB. Augmentative biological control concerns biopesticides, e.g., Lecanicillium as a pathogen of powdery mildews and some MB species (Pasaru et al. 2014), or in combination with Beauveria (Portilla et al. 2014).

\section{Conclusion}

A wealth of examples may be found in the literature regarding the co-occurrence of L\&F/M\&F feeding arthropods and biotrophic PFO, namely two-way interactions, but without reference to a three-way interaction with the plant (e.g., Rur 2016). In many cases, associations and causal effects are only suspected, while in others, an absence of effect has been put forward, supported or not by experimental findings.

All of the interaction pathways we reviewed (including pre-disposition, namely induced higher susceptibility or resistance resulting in cross-resistance/susceptibility, or a decrease/ increase in host plant resource quality for insects or pathogens), may overlap, while being synergistic or antagonistic, sometimes resulting in an absence of effect.

This review highlights new outlooks that could give rise to agroecological options for the management of both types of biotic aggressors.

Our recommendations on ACP against mango MB and powdery mildew could serve as a basis for ACP against other $\mathrm{MB}$ and PFO of the same guilds/lifestyles that damage other crops. Beyond the mere pest and pathogen regulation service, the ACP strategy contributes to other key ecosystem services, thus enhancing agroecosystem functioning.

Further research should also be focused on such biological models (= "pathosystems") on mango and other plants in order to obtain experimental findings on the suspected interactions (as already achieved for MB/grain mold on sorghum, also regarding potential interactions with climatic parameters), while also considering plant hormones and redox $/ \mathrm{pH}$ aspects (e.g., in the case of elemental sulfur application; Williams and Cooper 2004).

Acknowledgments The authors thank David Manley for English editing and Simon Ratnadass for artwork in Figs. 2 and 8.

\section{Compliance with ethical standards}

Funding This work has been carried out as part of the Cirad DPP COSAQ agronomical research program (period 2015-2020) funded by a grant from European Union (ERDF working program), the Regional Council of Reunion Island, and CIRAD.

Conflict of interest The authors declare that there is no conflict of interest.

Author contribution Writing, review, and editing: AR \& JPD

Ethical approval Not applicable

\section{References}

Agboton BV, Salifu D, Seguni Z, Sijaona ME, Shomari S, Maniania NK (2013) Bioecology of some key cashew insect pests and diseases in diverse habitats and landscapes in Tanzania. J Appl Entomol 137: 782. https://doi.org/10.1111/jen.12069

Aheto JH, Eziah VY, Atokple IDK, Opare-Obuobi K (2017) Sorghum head bug infestation and mould infection on the grain quality of sorghum in northern Ghana. Afr Crop Sci J 25:349. https://doi.org/ 10.4314/acsj.v25i3.8

Al-Naemi F, Hatcher PE (2013) Contrasting effects of necrotrophic and biotrophic plant pathogens on the aphid Aphis fabae. Entomol Exp Appl 148:234. https://doi.org/10.1111/eea.12091

Amarasekare KG, Shearer PW (2013) Laboratory bioassays to estimate the lethal and sublethal effects of various insecticides and fungicides on Deraeocoris brevis (Hemiptera: Miridae). J Econ Entomol 106: 776. https://doi.org/10.1603/EC12432

Arno J, Castane C, Riudavets J, Gabarra R (2010) Risk of damage to tomato crops by the generalist zoophytophagous predator Nesidiocoris tenuis (Reuter) (Hemiptera: Miridae). Bull Entomol Res 100:105. https://doi.org/10.1017/S0007485309006841

Atiama M (2016) Bioécologie et diversité génétique d'Orthops palus (Heteroptera, Miridae). In: ravageur du manguier à La Réunion. Université de La Réunion, $\mathrm{PhD}$ thesis

Babin R, Ten Hoopen GM, Cilas C, Enjalric F, Yede GP, Lumaret JP (2010) Impact of shade on the spatial distribution of Sahlbergella singularis in traditional cocoa agroforests. Agric Forest Entomol 12: 69. https://doi.org/10.1111/j.1461-9563.2009.00453.x

Bagny-Beilhe L, Piou C, Tadu Z, Babin R (2018) Identifying ant-mirid spatial interactions to improve biological control in cacao-based 
agroforestry system. Environ Entomol 47(23):551. https://doi.org/ 10.1093/ee/nvy018

Bandyopadhyay R, Butler DR, Chandrashekar A, Reddy RK, Navi SS (2000) Biology, epidemiology and management of sorghum grain mold. In: Chandrashekar A, Bandyopadhyay R, Hall AH (eds) Technical and Institutional Options for Sorghum Grain Mold Management: Proceedings of an International Consultation, 18-19 May 2000. ICRISAT, Patancheru, pp 34-71

Barzman M, Bàrberi P, Birch ANE, Boonekamp P, Dachbrodt-Saaydeh S, Graf B, Hommel B, Jensen JE, Kiss J, Kudsk P, Lamichhane JR, Messéan A, Moonen AC, Ratnadass A, Ricci P, Sarah JL, Sattin M (2015) Eight principles of integrated pest management. Agron Sustain Dev 35:1199-1215. https://doi.org/10.1007/s13593-0150327-9

Bech R (1967) Zur bedeutung der Lygus - Arten als Pflanzenschaedlinge. Importance of Lygus species as plant pests. Biologisches Zentralblatt 2:205

Bisseleua DHB, Begoude D, Tonnang H, Vidal S (2017) Ant-mediated ecosystem services and disservices on marketable yield in cocoa agroforestry systems. Agric Ecosyst Environ 247:409. https://doi. org/10.1016/j.agee.2017.07.004

Blum MS, Traynham JG, Chidester JB, Boggus JD (1960) n-Tridecane and trans-2-Heptenal in scent gland of the rice stink bug Oebalus pugnax (F.). Science 132:1480

Bousset L, Ermel M, Soglonou B, Husson O (2019) A method to measure redox potential (Eh) and $\mathrm{pH}$ in agar media and plants shows that fungal growth is affected by and affects $\mathrm{pH}$ and Eh. Fungal Biol 123: 117. https://doi.org/10.1016/j.funbio.2018.11.008

Bout A, Muller MM, Mailleret L, Boll R, Poncet C (2011) Spatial and temporal associations of powdery mildew and two-spotted spidermite in greenhouses. Acta Hort 917:23. https://doi.org/10.17660/ ActaHortic.2011.917.2

Bruce TJA (2010) Tackling the threat to food security caused by crop pests in the new millennium. Food Sec 2:133. https://doi.org/10. 1007/s12571-010-0061-8

Cadou J (1994) Les Miridae du cotonnier en Afrique et à Madagascar. Coton Fibres Trop Série Les déprédateurs du cotonnier en Afrique tropicale et dans le reste du monde 8:1

Cech VT (1989) Beeinflussung der Trieb- und Blattentwicklung von Eichen durch Gelege von Weichwanzen (Het., Miridae) und Zwergzikaden (Hom., Jassidae). Effects on eggs laid by Miridae (Het.) and Jassidae (Hom.) on the development of the sheet and leaves of oaks. Anz Schädlingskde Pflanzenschutz Umweltschutz 62:81

Cobben RH (1978) Evolutionary trends in Heteroptera. Part II. Mouthpart structures and feeding strategies. Meded Landbouwhogesch Wageningen 78:1

Constant B, Grenier S, Febvay G, Bonnot G (1996) Host plant hardness in oviposition of Macrolophus caliginosus (Hemiptera: Miridae). J Econ Entomol 89:1446. https://doi.org/10.1093/jee/89.6.1446

Coyier DL (1983) Control of rose powdery mildew in the greenhouse and field. Plant Dis 67:919

Crowdy SH (1947) Observations on the pathogenicity of Calonectria rigidiuscula (Berk. \& Br.) Sacc. on Theobroma cacao L. Ann Appl Biol 34:45

d'Ovidio R, Raiola A, Capodicasa C, Devoto A, Pontiggia D, Roberti S et al (2004) Characterization of the complex locus of bean encoding polygalacturonase-inhibiting proteins reveals subfunctionalization for defense against fungi and insects. Plant Physiol 135:2424. https://doi.org/10.1104/pp.104.044644

Dara SK (2017) Compatibility of the entomopathogenic fungus Beauveria bassiana with some fungicides used in California strawberry. Open Plant Sci J 10:29. https://doi.org/10.2174/ 1874294701710010029

De Lucca AJ, Carter-Wientjes CH, Boué S, Bhatnagar D (2011) Volatile trans-2-hexenal, a soybean aldehyde, inhibits Aspergillus flavus growth and aflatoxin production in corn. J Food Sci 76:M381M386. https://doi.org/10.1111/j.1750-3841.2011.02250.x

De Vos M, Van Oosten VR, Van Poecke RMP, Van Pelt JA, Pozo MJ, Mueller MJ, Buchala AJ, Metraux J-P, Van Loon LC, Dicke M et al (2005) Signal signature and transcriptome changes of Arabidopsis during pathogen and insect attack. Mol Plant Microbe Interact 18: 923. https://doi.org/10.1094/MPMI-18-0923

Deguine JP, Gloanec C, Laurent P, Ratnadass A, Aubertot JN (eds) (2017) Agroecological crop protection. Dordrecht, The Netherlands: Springer; Versailles, France: Ed. Quae

Deguine JP, Jacquot M, Allibert A, Chiroleu F, Graindorge R, Laurent P, Lambert G, Albon B, Marquier M, Gloanec C, Vanhuffel L, Vincenot D, Aubertot JN (2018) Agroecological protection of mango orchards in La Réunion. Sustain Agric Rev 28:249. https://doi. org/10.1007/978-3-319-90309-5 8

Demirel N, Cranshaw W, Norton A (2005) Survey of Lygus spp. and an associated parasitoid, Leiophron uniformis (Gahan), in Colorado. Southwest Entomol 30:9-15

Dietrick EJ (1961) An improved backpack motor fan for suction sampling of insect populations. J Econ Entomol 54:394

Fernandez D, Beers E, Brunner J, Doerr M, Dunley J (2006) Horticultural mineral oil applications for apple powdery mildew and codling moth, Cydia pomonella (L.). Crop Prot 25:585. https://doi.org/10. 1016/j.cropro.2005.08.014

Fernandez-Conradi P, Jactel H, Robin C, Tack AJM, Castagneyrol B (2018) Fungi reduce preference and performance of insect herbivores on challenged plants. Ecology 99:300. https://doi.org/10. 1002/ecy.2044

Ferran A, Rortais A, Malausa JC, Gambier J (1996) Ovipositional behaviour of Macrolophus caliginosus (Heteroptera: Miridae) on tobacco leaves. Bull Entomol Res 86:123. https://doi.org/10.1111/j.15707458.2005.00268.x

Frati F, Galletti R, Lorenzo GD, Salerno G, Conti E (2006) Activity of endo-polygalacturonases in mirid bugs (Heteroptera: Miridae) and their inhibition by plant cell wall proteins (PGIPs). Eur J Entomol 103:515. https://doi.org/10.14411/eje.2006.067

Gidoin C, Babin R, Bagny-Beilhe L, Cilas C, Ten Hoopen GM, Ngo Bieng MA (2014) Tree spatial structure, host composition and resource availability influence mirid density or black pod prevalence in cacao agroforests in Cameroon. PloS One 9(10):e109405. https:// doi.org/10.1371/journal.pone.0109405

Gopalan M, Basheer M (1966) Studies on the biology of Ragmus importunitas Distant (Hemiptera:Miridae) on sunnhemp. Madras Agric J 53:22

Gopalan M, Subramaniam TR (1978) Effect of infestation of Ragmus importunitas Distant (Hemiptera: Miridae) on respiration, transpiration, moisture content and oxidative enzymes activity in sunn-hemp plants (Crotalaria juncea L.). Curr Sci 47:131

Halitschke R, Hamilton JG, Kessler A (2011) Herbivore-specific elicitation of photosynthesis by mirid bug salivary secretions in the wild tobacco Nicotiana attenuata. New Phytol 191:528. https://doi.org/ 10.1111/j.1469-8137.2011.03701.x

Hatcher PE (1995) Three-way interactions between plant pathogenic fungi, herbivorous insects and their host plants. Biol Rev 70:639

Hauser P, Christensen S, Heimes C, Kiæret LP (2013) Combined effects of arthropod herbivores and phytopathogens on plant performance. Funct Ecol 27:623. https://doi.org/10.1111/1365-2435.12053

Haverkort AJ, Boonekamp PM, Hutten R, Jacobsen E, Lotz LAP, Kessel GJT, Visser RGF, van der Vossen EAG (2008) Societal costs of late blight in potato and prospects of durable resistance through cisgenic modification. Potato Res 51:47. https://doi.org/10.1007/s11540008-9089-y

Heidel AJ, Baldwin IT (2004) Microarray analysis of salicylic acid- and jasmonic acid signalling in responses of Nicotiana attenuata to attack by insects from multiple feeding guilds. Plant Cell Environ 27: 1362 
Hori K (1974) Plant growth-promoting factor in the salivary gland of the bug, Lygus disponsi. J Insect Physiol 20:1623

Hori K (2000) Possible causes of disease symptoms resulting from the feeding of phytophagous Heteroptera. In: Schaefer CW, Panizzi AR. Heteroptera of economic importance. CRC, Boca Raton, pp 11-35

Husson O (2013) Redox potential (Eh) and pH as drivers of soil/plant/ microorganism systems: a transdisciplinary overview pointing to integrative opportunities for agronomy. Plant Soil 362:389. https:// doi.org/10.1007/s11104-012-1429-7

Husson O, Husson B, Brunet A, Babre D, Alary K, Sarthou JP, Charpentier H, Durand M, Benada J, Henry M (2016) Practical improvements in soil redox potential (Eh) measurement for characterisation of soil properties. Application for comparison of conventional and conservation agriculture cropping systems. Anal Chim Acta 906:98. https://doi.org/10.1016/j.aca.2015.11.052

Husson O, Brunet A, Babre D, Charpentier H, Durand M, Sarthou JP (2018) Conservation agriculture systems alter the electrical characteristics (Eh, $\mathrm{pH}$ and EC) of four soil types in France. Soil Tillage Res 176:57. https://doi.org/10.1016/j.still.2017.11.005

Jacquot M (2016) Biodiversité et fonctionnement écologique des agroécosystemes à base de manguiers à $\mathrm{La}$ Réunion. $\mathrm{PhD}$ thesis, Université de La Réunion

Jiao Z, Jaworski CC, Lu Y, Ye L, Wu K, Desneux N (2019) Maize fields are a potential sink for an outbreaking mirid bug pest in Chinese Btcotton agricultural landscapes. Agric Ecosyst Environ 279:122. https://doi.org/10.1016/j.agee.2019.04.010

Joubert MH, Manicom BQ, Wingfield MJ (1993) Powdery mildew of mango in South Africa: a review. Phytophylactica 25:59

Karban R, Chen Y (2007) Induced resistance in rice against insects. Bull Entomol Res 97:327. https://doi.org/10.1017/S0007485307005056

Kessler A, Baldwin IT (2004) Herbivore-induced plant vaccination. Part I. The orchestration of plant defenses in nature and their fitness consequences in the wild tobacco Nicotiana attenuata. Plant J 38: 639. https://doi.org/10.1111/j.1365-313X.2004.02076.x

Koornneef A, Pieterse CMJ (2008) Cross-talk in defense signaling. Plant Physiol 146:839. https://doi.org/10.1104/pp.107.112029

Kraepiel Y, Barny MA (2016) Gram-negative phytopathogenic bacteria, all hemibiotrophs after all? Mol Plant Pathol 17:313. https://doi.org/ 10.1111/mpp. 12345

Kuepper G, Thomas R (2002) "Bug vacuums" for organic crop protection. ATTRA (Appropriate Technology Transfer for Rural Areas), University of Arkansas, Fayetteville, AR, $4 \mathrm{p}$

Laemmlen FF, Hall DH (1973) Interdependence of a mite, Siteroptes reniformis, and a fungus, Nigrospora oryzae, in the Nigrospora lint rot of cotton. Phytopathology 63:308. https://doi.org/10.1094/ Phyto-63-308

Leland JE, Mcguire MR, Grace JA, Jaronski S, Ulloa M, Park Y, Plattner RD (2005) Strain selection of a fungal entomopathogen, Beauveria bassiana, for control of plant bugs (Lygus spp.) (Heteroptera: Miridae). Biol Control 35:104. https://doi.org/10.1016/j.biocontrol. 2005.06.005

Li XG, Liu B, Heia S, Liu DD, Han ZM, Zhou KX, Cui JJ, Luo JY, Zheng YP (2009) The effect of root exudates from two transgenic insect-resistant cotton lines on the growth of Fusarium oxysporum. Transgenic Res 18:757. https://doi.org/10.1007/s11248-009-9264-1

Li J, Liu B, Pan H, Luo S, Wyckhuys KAG, Yuan H, Lu Y (2019) Buckwheat strip crops increase parasitism of Apolygus lucorum in cotton. BioControl 64:645. https://doi.org/10.1007/s10526-01909961-1

Logrieco A, Mulè G, Moretti A, Bottalico A (2002) Toxigenic Fusarium species and mycotoxins associated with maize ear rot in Europe. Eur J Plant Pathol 108:597. https://doi.org/10.1023/A:1020679029993

Lu YH, Wu KM, Wyckhuys KAG, Guo YY (2009) Potential of mungbean, Vigna radiatus as a trap crop for managing Apolygus lucorum (Hemiptera: Miridae) on Bt cotton. Crop Prot 28:77. https:// doi.org/10.1016/j.cropro.2008.08.018
Lu YH, Wu KM, Jiang YY, Xia B, Li P, Feng HQ, Wyckhuys KAG et al (2010) Mirid bug outbreaks in multiple crops correlated with widescale adoption of Bt cotton in China. Science 328:1151. https://doi. org/10.1126/science.1187881

Mahot HC, Membang G, Begoude BAD, Bagny-Beilhe L, Bilong Bilong CF (2019) Laboratory assessment of virulence of Cameroonian isolates of Beauveria bassiana and Metarhizium anisopliae against mirid bugs Sahlbergella singularis Haglund (Hemiptera: Miridae). Afric Entomol 27:86. https://doi.org/10.4001/003.027.0086

Marley PS, Ajayi O (1999) Sorghum grain mold and the influence of head-bug Eurystylus oldi in West and Central Africa. J Sustain Agric 13:35

Marley PS, Malgwi A (1999) Incidence of head bugs (Eurystylus sp.) on sorghum grain mould in the Nigerian savanna. J Agric Sci 132:71

Martin WR Jr, Grisham MP, Kenerley CM, Sterling WL, Morgan PW (1987) Microorganisms associated with cotton fleahopper. Ann Entomol Soc Amer 80:251

McLoud LA, Knutson A, Campos-Figueroa M, Smith CW, Hague S (2015) Evaluating pilose, a cultigen of Gossypium hirsutum, as a source of resistance to cotton fleahopper (Hemiptera: Miridae). J Econ Entomol 108:2048. https://doi.org/10.1093/jee/tov128

Meng S, Torto-Alalibo T, Chibucos MC et al (2009) Common processes in pathogenesis by fungal and oomycete plant pathogens, described with Gene Ontology terms. BMC Microbiol 9:S7. https://doi.org/10. 1186/1471-2180-9-S1-S7

Miles PW (1978) Redox reactions of Hemipterous saliva in plant tissues. Entomol Exp Appl 24:334

Misra AK (2001) Powdery mildew - a serious disease of mango. J Appl Hortic 3:63

Misra AK, Prakash O, Pandey BK (1998) Calender of operations... for integrated disease management in mango. Indian Hortic 43:12

Mitchell PL (2004) Heteroptera as vectors of plant pathogens. Neotrop Entomol 33:519. https://doi.org/10.1590/S1519566X2004000500001

Mohammadi H, Pakkish Z, Saffari V (2015) Role of methyl jasmonate and salicylic acid applications on bloom delay, flowering and fruiting of 'Elberta' Peach. Int J Hortic Sci Tech 2:75

Mondy N, Corio-Costet MF (2004) Feeding insects with a phytopathogenic fungus influences their diapause and population dynamics. Ecol Entomol 29:711. https://doi.org/10.1111/j.0307-6946.2004. 00642.x

Moran PJ (1998) Plant-mediated interactions between insects and a fungal plant pathogen and the role of plant chemical responses to infection. Oecologia 115:523

Nasir M, Mughal SM, Mukhtar T, Awan MZ (2014) Powdery mildew of mango: a review of ecology, biology, epidemiology and management. Crop Prot 64:19. https://doi.org/10.1016/j.cropro.2014.06. 003

Oerke EC (2006) Crop losses to pests. J Agr Sci 144:31-43. https://doi. org/10.1017/S0021859605005708

Oliveira CM, Auad AM, Mendes SM, Frizzas MR (2014) Crop losses and the economic impact of insect pests on Brazilian agriculture. Crop Prot 56:50. https://doi.org/10.1016/j.cropro.2013.10.022

Oosthuyse S, Jacobs J (1997) Flowering synchronization of Sensation mango trees by winter pruning. South Afri Mango Grow Assoc Yearb 17:47

Ownley BH, Griffin MR, Klingeman WE, Gwinn KD, Moulton JK, Pereira RM (2008) Beauveria bassiana: endophytic colonization and plant disease control. J Invert Pathol 98:267. https://doi.org/ 10.1016/j.jip.2008.01.010

Pallas V, Garcia JA (2011) How do plant viruses induce disease? Interactions and interference with host components. J Gen Virol 92:2691. https://doi.org/10.1099/vir.0.034603-0

Pan H, Lu Y, Wyckhuys KAG, Wu K (2013) Preference of a polyphagous mirid bug, Apolygus lucorum (Meyer-Dür) for flowering host 
plants. PLoS One 8:e68980. https://doi.org/10.1371/journal.pone. 0068980

Pappas M, Steppuhn A, Geuss D, Topalidou N, Zografou A, Sabelis MW, Broufas GD (2015) Beyond predation: the zoophytophagous predator Macrolophus pygmaeus induces tomato resistance against spider mites. PLoS One 10:e0127251. https://doi.org/10.5061/ dryad.3754b

Pappas ML, Steppuhn A, Broufas GD (2016) The role of phytophagy by predators in shaping plant interactions with their pests. Commun Integr Biol 9:1. https://doi.org/10.1080/19420889.2016.1145320

Pasaru F, Anshary A, Kuswinanti T, Mahfudz S (2014) Prospective of entomopathogenic fungi associated with Helopeltis spp. (Hemiptera: Miridae) on cacao plantation. Int J Curr Res Aca Rev 2:227

Peña JE, Glenn H, Baranowski RM (2003) Dynamics and sampling of mirids (Hemiptera: Miridae) in avocado in Florida. In: Anon (ed.) Proceedings V World Avocado Congress, 19-24 October 2003, Granada-Málaga, Spain, pp 495-501

Pérez-Hedo M, Urbaneja A (2015) Prospects for predatory mirid bugs as biocontrol agents of aphids in sweet peppers. J Pest Sci 88:65. https://doi.org/10.1007/s10340-014-0587-1

Poncet C, Bout A, Muller MM, Mailleret L (2008) Direct and indirect interactions between powdery mildew and spider mite populations in greenhouse rose crops. Acta Hort 797:229. https://doi.org/10. 17660/ActaHortic.2008.797.31

Ponzio C, Gols R, Pieterse CMJ, Dicke M (2013) Ecological and phytohormonal aspects of plant volatile emission in response to single and dual infestations with herbivores and phytopathogens. Funct Ecol 27:587. https://doi.org/10.1111/1365-2435.12035

Portilla M, Snodgrass G, Luttrell R, Jaronski S (2014) A novel bioassay to evaluate the potential of Beauveria bassiana strain NI8 and the insect growth regulator novaluron against Lygus lineolaris on a nonautoclaved solid artificial diet. J Insect Sci 14:115. https://doi.org/ 10.1093/jis/14.1.115

Ratnadass A, Butler DR (2003) Abundance of sorghum panicle-feeding bugs (Hemiptera: Miridae) in Mali and empirical relationships with weather. Insect Sci Applic 23:339

Ratnadass A, Doumbia YO, Ajayi O (1995) Bioecology of sorghum head bug Eurystylus immaculatus and crop losses in West Africa. In: Nwanze KF, Youm O (eds) Panicle insect pests of sorghum and pearl millet. Proceedings of an international consultative workshop, 4-7 October 1993, ICRISAT Sahelian Center, Niamey, Niger. ICRISAT, Patancheru, pp 91-102

Ratnadass A, Hamada MAG, Traoré S, Cissé S, Sidibé B (2001) On-farm development and testing of IPM packages for control of sorghum head-bugs in Mali. Meded Fac Landbouwwet Rijksuniv Gent. 66: 315

Ratnadass A, Marley PS, Hamada MAG, Ajayi O, Cissé B, Assamoi F, Atokple IDK, Beyo J, Cissé O, Dakouo D, Diakité M, Dossou Yovo S, Le Diambo B, Vopeyande MB, Sissoko I, Tenkouano A (2003a) Sorghum head-bugs and grain molds in West and Central Africa: 1. Host plant resistance and bug-mold interactions on sorghum grains. Crop Prot 22:837. https://doi.org/10.1016/S0261-2194(03)00066-8

Ratnadass A, Butler DR, Marley PS, Bandyopadhyay R, Hess DE, Akintayo I (2003b) Sorghum head-bugs and grain molds in West and Central Africa: 2. Relationships between weather, head-bug and mold damage on sorghum grains. Crop Prot 22:853. https://doi.org/ 10.1016/S0261-2194(03)00067-X

Ratnadass A, Togola M, Cissé B, Vassal JM (2009) Potential of sorghum and physic nut (Jatropha curcas) for management of plant bugs (Hemiptera: Miridae) and cotton bollworm (Helicoverpa armigera) on cotton in an assisted trap-cropping strategy. J SAT Agric Res 7:1

Ratnadass A, Fernandes P, Avelino J, Habib R (2012) Plant species diversity for sustainable management of crop pests and diseases in agroecosystems: a review. Agron Sustain Dev 32:273. https://doi. org/10.1007/s13593-011-0022-4
Ratnadass A, Soler A, Chabanne A, Tullus RG, Técher P, Le Bellec F, Marnotte P, Streito JC, Matocq A (2018) First record of Moissonia importunitas as a pest of rattlebox (Crotalaria spp.) in Réunion Island (Hemiptera, Miridae). Bull Soc Entomol Fr 123:59-64

Ratnadass A, Grechi I, Caillat A, Preterre AL, Normand F, Graindorge R (2019) Effects of some cultural practices on mango inflorescence and fruit pest infestation and damage in Reunion island: recent progress, on-going studies and future steps. Acta Hort 1244:159. https:// doi.org/10.17660/ActaHortic.2019.1244.24

Ray P, Hill MP (2016) More is not necessarily better: the interaction between insect population density and culture age of fungus on the control of invasive weed water hyacinth. Hydrobiologia 766:189. https://doi.org/10.1007/s10750-015-2454-3

Reding ME, Alston DG, Thomson SV, Stark AV (2001) Association of powdery mildew and spider mite populations in apple and cherry orchards. Agric Ecosyst Environ 84:177. https://doi.org/10.1016/ S0167-8809(00)00204-8

Romani R, Salerno G, Frati F, Conti E, Isidoro N, Bin F (2005) Oviposition behaviour in Lygus rugulipennis: a morpho-functional study. Entomol Exp Appl 115:17. https://doi.org/10.1111/j.15707458.2005.00268.x

Romero D, Rivera ME, Cazorla FM, De Vicente A, Perez-Garcia A (2003) Effect of mycoparasitic fungi on the development of Sphaerotheca fusca in melon leaves. Mycol Res 107:64. https:// doi.org/10.1017/S0953756202006974

Rostas M, Simon M, Hilker M (2003) Ecological cross-effects of induced plant responses towards herbivores and phytopathogenic fungi. Basic Appl Ecol 4:43. https://doi.org/10.1078/1439-1791-00132

Rothe M, Pelletier N, Touneji-Catouaria AM, Bockstaller C, Le Bellec F, Ratnadass A (2019) Impacts of weed management on ladybird (Coleoptera:Coccinellidae) abundance and diversity on resident vegetation in a citrus orchard. Int J Trop Insect Sci 39:325. https:// doi.org/10.1007/s42690-019-00055-0

Rur M (2016) Developing IPM tools for greenhouse cucumber production in Sweden - a participatory action research approach: control of the European tarnished plant bug and cucurbit powdery mildew. Licentiate Thesis, Swedish University of Agricultural Sciences, Alnarp

Saravanan P, Divya S, Venkatesan P, Tanwar R, Birah A, Chattopadhyay C, Jeyakumar P, Barik A (2015) Trend analysis of pests and diseases complex in Bt cotton. J Crop Prot 4:431

Savary S, Ficke A, Aubertot JN, Hollier C (2012) Crop losses due to diseases and their implications for global food production losses and food security. Food Secur 4:519. https://doi.org/10.1007/ s12571-012-0200-5

Sequeira R (2019) Integrated pest management of plant sucking bugs (Hemiptera: Miridae) in Australian cotton: back to the future. Bull Entomol Res 109:561. https://doi.org/10.1017/ S0007485318000950

Sharma A, Khan AN, Subrahmanyam S, Raman A, Taylor GS, Fletcher MJ (2014) Salivary proteins of plant-feeding hemipteroids - implication in phytophagy. Bull Entomol Res 104:117. https://doi.org/10. 1017/S0007485313000618

Singh VK, Saini JP, Misra AK (2001) Response of salicylic acid on flowering, floral malformation, fruit set, yield and associated biophysical and biochemical characters of mango. Indian J Hort 58:196

Sobhy IS, Erb M, Lou Y, Turlings TCJ (2014) The prospect of applying chemical elicitors and plant strengtheners to enhance the biological control of crop pests. Phil Trans R Soc B 369:20120283. https://doi. org/10.1098/rstb.2012.0283

Stephenson LW, Russell TE (1974) The association of Aspergillus flavus with hemipterous and other insects infesting cotton bracts and foliage. Phytopathology 64:1502. https://doi.org/10.1094/Phyto-641502

Steyaert RL, Vrydagh J (1933) Etude sur une maladie grave du cotonnier provoquée par les piqures d'Helopeltis. Mémoires Institut Royal 
Colonial Belge - Section des Sciences naturelles \& médicales, Collection in- $8^{\circ}$ Tome I, Fascicule 7.

Stout MJ, Thaler JS, Thomma BPHJ (2006) Plant-mediated interactions between pathogenic microorganisms and herbivorous arthropods. Ann Rev Entomol 51:663. https://doi.org/10.1146/annurev.ento. 51.110104 .151117

Thaler JS, Stout MJ, Karban R, Duffey SS (2001) Jasmonate-mediated induced plant resistance affects a community of herbivores. Ecol Entomol 26:312. https://doi.org/10.1046/j.1365-2311.2001.00324.x

Thaler JS, Humphrey PT, Whiteman NK (2012) Evolution of jasmonate and salicylate signal crosstalk. Trends Plant Sci 17:260. https://doi. org/10.1016/j.tplants.2012.02.010

Tonapi VA, Mundada RR, Navi SS, Reddy RK, Thakur RP, Bandyopadhyay R, Varanavasiappan S, Seetharama N (2007) Effect of temperature and humidity regimes on grain mold sporulation and seed quality in sorghum (Sorghum bicolor (L.) Moench). Arch Phytopathol Pflanzenschutz 40:113. https://doi.org/10.1080/ 03235400500355626

Turner K, Ravetta D, van Tassel D (2018) Effect of Puccinia silphii on yield components and leaf physiology in silphium integrifolium: lessons for the domestication of a perennial oilseed crop. Sustainability 10:696. https://doi.org/10.3390/su10030696

Vallad GE, Goodman RM (2004) Systemic acquired resistance and induced systemic resistance in conventional agriculture. Crop Sci 44: 1920. https://doi.org/10.2135/cropsci2004.1920

Vega FE, Blackwell M (2005) Insect-fungal associations: ecology and evolution. Oxford University Press, New York

Vincenot D, Normand F (2009) Guide de production intégrée de mangues à la Réunion. CIRAD et Chambre d'Agriculture, Saint-Pierre, Ile de la Réunion, France, $121 \mathrm{p}$

Voelckel C, Baldwin IT (2004) Herbivore-induced plant vaccination. Part II. Array-studies reveal the transience of herbivore-specific transcriptional imprints and a distinct imprint from stress combinations. Plant J 38:650. https://doi.org/10.2135/cropsci2004.1920

Vrydagh JM (1936) Contribution à l'étude de la maladie des chancres des tiges du cotonnier causé par Helopeltis bergrothi Reut. Bull Agric Congo belge 27:1

Walling LL (2000) The myriad plant responses to herbivores. J Plant Growth Regul 19:195. https://doi.org/10.1007/s003440000026

Wheeler AG Jr (1981) The tarnished plant bug: cause of potato rot?: an episode in mid-nineteenth-century entomology and plant pathology. J Hist Biol 14:317-338

Wheeler AG Jr (2001) Biology of the plant bugs (Hemiptera: Miridae): pests, predators, opportunists. Comstock Publishing Associates, Ithaca

Whitwell AC (1993) The pest/predator/parasitoid complex on mango inflorescences in Dominica. Acta Hort 341:421. https://doi.org/10. 17660/ActaHortic.1993.341.47

Wielgoss A, Clough Y, Fiala B, Rumede A, Tscharntke T (2012) A minor pest reduces yield losses by a major pest: plant-mediated herbivore interactions in Indonesian cacao. J Appl Ecol 49:465. https://doi.org/ 10.1111/j.1365-2664.2012.02122.x
Wijetunge PMAPK, Ahangama D, Ranaweera B (2003) Biology of the cashew pest Helopeltis antonii Sign. and its predators. Trop Agric Res 15:188

Williams JS, Cooper RM (2004) The oldest fungicide and newest phytoalexin - a reappraisal of the fungitoxicity of elemental sulphur. Plant Pathol 53:263. https://doi.org/10.1111/j.0032-0862.2004. 01010.x

Williams L, Logarzo GA, Shaw SR, Price LD, Manrique V (2003) Leiophron argentinensis Shaw (Hymenoptera: Braconidae): a new species of parasitoid from Argentina and Paraguay - information on life history and potential for controlling Lygus bugs (Hemiptera: Miridae). Ann Entomol Soc Am 96:834. https://doi.org/10.1603/ 0013-8746(2003)096[0834:LASHBA]2.0.CO;2

Willsey T, Chatterton S, Cárcamo H (2017) Interactions of root-feeding insects with fungal and oomycete plant pathogens. Front Plant Sci 8: 1764. https://doi.org/10.3389/fpls.2017.01764

Wood W, Gore J, Catchot A, Cook D, Dodds D, Krutz LJ (2017) Effect of leaf pubescence on tarnished plant bug (Hemiptera: Miridae) ability to cause damage and yield loss in cotton. J Cotton Sci 21:122

Worrall D, Holroyd GH, Moore JP, Glowacz M, Croft P, Taylor JE, Paul ND, Roberts MR (2012) Treating seeds with activators of plant defence generates long-lasting priming of resistance to pests and pathogens. New Phytol 193:770. https://doi.org/10.1111/j.14698137.2011.03987.x

Yarwood C (1943) Association of thrips with powdery mildews. Mycologia 35:189. https://doi.org/10.2307/3754709

Zappalà L, Siscaro G, Biondi A, Mollà $\mathrm{O}$, Gonzàlez-Cabrera J, Urbaneja A (2011) Efficacy of sulphur on Tuta absoluta and its side effects on the predator Nesidiocoris tenuis. J Appl Entomol 17:401. https://doi. org/10.1111/j.0032-0862.2004.01010.x

Zhang Z, Luo J, Wang Y, Chen L, Chen L, Lei C (2014) Morphology and chemical analysis of the metathoracic scent glands system in Adelphocoris suturalis (Hemiptera: Miridae). J Insect Sci 14:293. https://doi.org/10.1093/jisesa/ieu155

Zhang L, Xu P, Xiao H, Lu Y, Liang G, Zhang Y et al (2015) molecular characterization and expression profiles of polygalacturonase genes in Apolygus lucorum (Hemiptera: Miridae). PLoS One 10: e0126391. https://doi.org/10.1371/journal.pone.0126391

Zhang Z, Wang Y, Zhao Y, Li B, Lin J, Zhang X, Liu F, Mu W (2017) Nitenpyram seed treatment effectively controls against the mirid bug Apolygus lucorum in cotton seedlings. Sci Rep 7:8573. https://doi. org/10.1038/s41598-017-09251-9

Zhang NX, Messelink GJ, Alba JM et al (2018) Phytophagy of omnivorous predator Macrolophus pygmaeus affects performance of herbivores through induced plant defences. Oecologia 186:101. https:// doi.org/10.1007/s00442-017-4000-7

Publisher's note Springer Nature remains neutral with regard to jurisdictional claims in published maps and institutional affiliations. 